\title{
Mountain Hunting Land Lands of the Best Sirvan Region the Effects of the Erosion Process on Municipality (in the Case of Shamakhi Region)
}

\author{
Prof. RANS ZH.Aliyev \\ Institute of Soil Science and Agrochemistry of ANAS \\ zakirakademik@mail.ru
}

\section{Annotation:}

The aim of the study is to investigate the erosion of degraded brown soils used mainly under grain crops in the Shamakhi region, south-east of the Greater Caucasus, and erosion of moderately eroded species to the soil fertility parameters.

Keywords: soil, erosion, erosion and moderately eroded soils, fertility.

\section{Introduction}

In order to identify ways to increase soil fertility in modern agriculture, a scientific analysis of the specific properties of each soil should be given in order to be able to accurately determine the characteristics of soils in different regions. It is impossible to use these lands effectively and to get any crop from agricultural plants. Because of the fact that the soil is used for a long time under some or other plants (often under the same plant), their agrochemical composition and other properties become worse.

It is possible to develop and improve the management of the lost soil fertility by taking into account them only in the development of agriculture. The research was also devoted to studying this issue.

The object and method of research

The study was carried out in eroded and moderately eroded species of degraded brown soils spreading in the vertical direction of the Shamakhi region and forming the main fund of mountain farming on the southeastern slope of the Greater Caucasus. Soil samples were taken from their genetic layers and analyzed in laboratory conditions, where erosion was not eroded to study the effects of erosion on land fertility, and in medium-eroded cuttings in natural (harvesting) areas.

Degree of soil erosion is determined on the scale of S.Sobolevin and KA Alekperov $(1,2)$. The Shamakhi region is bordered by Guba in the north-west, Khizi in the north-west, Gobustan in the south-east, Hajigabul in the south, Aghsu in the south-west and west, and Ismayilli in the north-west.

\section{Analysis and discussion}

The Southeastern Caucasus, including the Shamakhi region, has a complex geological and geomorphological structure. Because of the complexity of natural conditions and the influence of anthropogenic factors, the erosion process in the area has widespread and has deteriorated soil fertility.

Depending on where Relyev is moving vertically, this region is separated into four main altitude zones, which differ sharply from each other:

1. High mountain range (2200 $\mathrm{m}$ above sea level and above);

2. Medium mountain range (800-1000 m above sea level up to $2000-2300 \mathrm{~m}$ );

3. Low mountain ranges and foothills (200 $\mathrm{m}$ to $1000 \mathrm{~m}$ ); 


\section{Seamless girdle ( $28 \mathrm{~m}$ to $200 \mathrm{~m})$}

Erosion has grown stronger in the central part of the low mountainous belt relative to the highlands. According to the modern geomorphological division BABudagov refers to the low mountain range of the Greater Caucasus, separating the Shamakhi-Gobustan regions by several half-lives (5).

The agricultural zone of the region is mainly composed of medium, low mountainous and foothills.

The erosion process in the agricultural zone of the region has intensified and has spoiled large areas. The main reason for the erosion process in the mountain-farming zone of the region and its spread to large areas is the lack of attention to ordinary soil-protective agrotechnical measures on the slopes, non-extraction of sowing, sowing and other cultivation.

The use of slopes in the middle and low mountainous zones, mainly under grain crops and low slopes, in the grape plantations, has also led to erosion strengthening and extensive coverage. Almost all types and types of erosion are found in Shamakhi region. Studies show that the mountainous-brown soils that are used intensively in mountainous cultivation in the middle and low mountainous areas of the region have been exposed to erosion. [3,4].

These lands are mainly formed of low-oak, brown mountain-forest lands developed under oak-vulture forests. The formation of mountain steppes in the areas without systematic breaks of the forests and the occurrence of degraded brown soils in these areas.

Brown mountain-forested lands are relatively dry (with a rainfall of $400-500 \mathrm{~mm}$ ) in climatic conditions. Here, the rocks that form the land are primarily of carbonate rocks or their abrasive products, clayey schists, erats. These soils are selected by the thickness of the humus layer, the humus mass, the relative distribution along the profile, the high absorption capacity, the neutral or the weak alkaline, the clay content of the mechanical composition, the high concentration of carbonates in the middle layer.

The formation of degraded brown soils, morphological signs, H. Aliyev (1972), ME Salayev (1966), KA Alekberov (1961) and other researchers gave detailed information about their genetic features and other properties $(6,7)$.

For long periods of time under cultivation of agricultural crops, the grass landslides have disappeared from the upper layers of dark-brown soils in the sown areas and have not been planted, and some of their characteristics are closely related to stony landscapes (mountain black and gray-brown).

However, the weak profile of the profile, especially in the middle layer, is characterized by the fact that the majority of carbonates have come from the bottom of the forest.

The erosion has not been eroded to characterize the morphological features of the degraded brown soils and has been drilled to a moderately eroded natural area. Morphological signs of the erosion type of these lands are given in desert description of the 1 st figure.

1. A1 0-12 cm of dark giant garnet, dandyworld, elephantic, soft, semi-dry, cuckoo, wormwood, porous, heavy herbaceous crustacea, nanam, moonlit, $\mathrm{HCl}$ 's tyiridine garnish.

2. A2 $12-37 \mathrm{~cm}$ - alfalfa, dark giant, large topavaryvanwarya, soft, semi cuckoo, cuckoo, wormwood, semi-rotten plant residues, brown leaks, moisture, dandruff delay, gneis.

3. B 37-58 cm - elliptic, light brown, unwanted cauliflower, soft, celiac cucumber, cucumber, brown spots, dried root hair, nana, moon's nighttime, thyme thyroid gneiss. 
4. C 48-97 cm, yellowish brown (brownish) structure is selected, slightly soluble, single-grained roots, sparse, weakly whitish spots and boils. Morphological signs of eroded soils are given in Desert Tree 2.

1. A1 0-9 cm is an elliptic, open gyachesva (bozumtul), splinters (pollinated), soft, sugar, cucumbers, herbs, worm paths, nanometers, moon latrines, titanium glycerol of $\mathrm{HCl}$.

2. B 9-32 cm - alfalfa, open guschvyai (bozumtul), splinters (softened), soft, suckers, cuckoo, plant scraps, worm paths, nanometers, moon latrines, Tiiririndian zinc of $\mathrm{HCl}$.

3. C 32-55 cm - alfalfa, stubble brown, structure not selected, solid, single lime limestone, sparse thin roots, moisture, garnet. It is clear from the morphological description that the structure of these lands has dramatically changed after the forest (especially in moderately erosive species). In the middle only, the structure of the scaffold is very poorly selected.

At the moderately eroded type, the soil structure has been completely eroded.

Numerous studies have shown that the importance of the structure is great, affecting the soil's aerosol, and its erosion resistance. Structural soils have more than $40-50-100 \%$ of their crops on the structured soils. The mechanical composition of the brown-brown soils is agglomerated with gill and clay.

This is evident from both the morphological description and the results of the analysis. In the soil we describe, the amount of physical clay varies between $49.92-59.75 \%$ in the moderately eroded type of $56.20-63.76 \%$. The relatively small degree of physical cilia in the moderately eroded type shows that pomegranate particles were washed off as a result of incorrect use of the soil. The majority of lil particles in these deposits are due to the presence of illudial horizons in these soils. In the moderately eroded degraded brown soils, this does not seem to be so significant because the erosion process has resulted in considerable changes in the genetic layer.

When compared to the non-erosion type of soils, it is clear that the humus at the top of the erosion type is 2.35 $\%$ total nitrogen $0.193 \%$, absorbed ammonia $42.27 \mathrm{mg} / \mathrm{kg}$, water-soluble ammonia 8,74 mg / kg, nitrates 3,48 $\mathrm{mg} / \mathrm{kg}$, persistent phosphorus $12,51 \mathrm{mg} / \mathrm{kg}$, exchanged potassium $117,66 \mathrm{mg} / \mathrm{kg}$, respectively, in the lower layers 1.11-1.53; 0.060-0.159\%; 10,75-4574; 5,76-8,58; 0.79-2.76; 10, 34-15,69 and 15,80-221,40 mg / kg. Table 1. Because of the high absorption ability of these soils, the amount of absorbed bases ( $\mathrm{Ca}$ and $\mathrm{Mg}$ ) is relatively high.

However, these indicators were significantly lower in the erosion type. Thus, the total amount of absorbed bases ( $\mathrm{Ca}$ and $\mathrm{Mg}$ ) declined to $9.67-11.31 \mathrm{mg}$ per square centimeter in 15,40 cubic meters (100 $\mu \mathrm{g}$ of soil) in the upper layer in moderately eroded soils compared to non-eroded soils.

Profile throughout the total moisture $22.38-27.50 \%$ in soil erosion, and moderate erosion was $16.64-19.38 \%$. In soil fertility, water washed, wind resistant to wind destructive forces, str 
Table 1 Some agrochemicals of grassy mountainous grasses

\begin{tabular}{|c|c|c|c|c|c|c|c|c|c|c|c|c|c|}
\hline \multirow{2}{*}{$\begin{array}{c}\text { Num } \\
\text { ber } \\
\text { № }\end{array}$} & \multirow{2}{*}{$\begin{array}{l}\text { Genet } \\
\text { ic } \\
\text { layers }\end{array}$} & \multirow[t]{2}{*}{$\begin{array}{l}\text { Depth } \\
\text { of sm }\end{array}$} & \multirow[t]{2}{*}{$\begin{array}{l}\text { Hum } \\
\text { us\% }\end{array}$} & \multirow{2}{*}{$\begin{array}{c}\text { Tota } \\
\text { I } \\
\text { nitro } \\
\text { gen } \\
\text { in\% }\end{array}$} & \multicolumn{3}{|c|}{$\begin{array}{l}\text { Forms of nitrogen } \mathbf{m g} \\
\qquad / \mathbf{k g}\end{array}$} & \multicolumn{2}{|c|}{ Phosphorus } & \multicolumn{2}{|c|}{ Kalium } & \multirow{2}{*}{$\begin{array}{c}\mathrm{CaC} \\
\mathrm{O}_{3} \\
\%\end{array}$} & \multirow[t]{2}{*}{ Pn } \\
\hline & & & & & $\begin{array}{c}\text { Amazi } \\
\text { ng } \\
\text { acne }\end{array}$ & $\begin{array}{c}\text { Ammo } \\
\text { nia } \\
\text { soluble } \\
\text { in } \\
\text { water }\end{array}$ & $\begin{array}{c}\text { Nitr } \\
\text { ate } \\
s\end{array}$ & $\begin{array}{l}\text { Perc } \\
\text { ent } \\
\text { of } \%\end{array}$ & $\begin{array}{c}\text { Mobile } \\
\text { mg / } \\
\text { kg }\end{array}$ & $\begin{array}{c}\text { Perc } \\
\text { ent } \\
\text { of\% }\end{array}$ & $\begin{array}{c}\text { Purpos } \\
\text { e } \\
\text { mg / } \\
\text { kg }\end{array}$ & & \\
\hline \multicolumn{14}{|c|}{ no erosion } \\
\hline \multirow{4}{*}{1} & $A_{1}$ & $0-12$ & 5,15 & 0,412 & 123,19 & 20,64 & 7,94 & 0,27 & 27,93 & 3,15 & 399,00 & no & 7,0 \\
\hline & $\mathbf{A}_{2}$ & $12-37$ & 3,21 & 0,280 & 107,10 & 18,90 & 6,30 & 0,22 & 29,03 & 3,10 & 368,20 & no & 7,0 \\
\hline & B & $37-58$ & 2.23 & 0,118 & 74,40 & 13,95 & 4,03 & 0,13 & 15,54 & 2,97 & 315,00 & 4,54 & 7,2 \\
\hline & C & $58-97$ & 0,92 & 0,088 & 64,44 & 10,67 & 3,05 & 0,10 & 7,32 & 2,94 & 130,75 & 4,85 & 7,3 \\
\hline \multicolumn{14}{|c|}{ Medium degree of erosion } \\
\hline \multirow{3}{*}{2} & $A_{2}$ & $0-9$ & 3,07 & 0,219 & 70,92 & 11,90 & 4,46 & 0,17 & 15,42 & 2,20 & 281,34 & 5,39 & 7,5 \\
\hline & Б & $9-32$ & 2,31 & 0,131 & 61,36 & 10,32 & 3,54 & 0,15 & 13,34 & 2,25 & 208,40 & 7,61 & 7,7 \\
\hline & BC & $32-55$ & 0,70 & 0,058 & 52,65 & 8,19 & 2,34 & 0,08 & 5,20 & 2,80 & 93,60 & 6,81 & 7,5 \\
\hline
\end{tabular}


Table 2. Some agrochemicals of grassy mountainous grasses

\begin{tabular}{|c|c|c|c|c|c|c|c|c|c|c|c|c|c|}
\hline \multirow{2}{*}{$\begin{array}{c}\text { Nu } \\
\text { mbe } \\
\text { r } \\
\text { № }\end{array}$} & \multirow{2}{*}{$\begin{array}{c}\text { Gene } \\
\text { tic } \\
\text { layer } \\
s\end{array}$} & \multirow[t]{2}{*}{$\begin{array}{l}\text { Depth } \\
\text { of sm }\end{array}$} & \multirow{2}{*}{$\begin{array}{l}\text { Shhu } \\
\text { mus } \\
\text { \% La }\end{array}$} & \multirow{2}{*}{$\begin{array}{c}\text { Cmu } \\
\text { mi } \\
\text { nitro } \\
\text { gen } \\
\% \text { La }\end{array}$} & \multicolumn{3}{|c|}{$\begin{array}{l}\text { Forms of nitrogen } \\
\mathrm{mg} / \mathbf{k g}\end{array}$} & \multicolumn{2}{|c|}{ Phosphorus } & \multicolumn{2}{|c|}{ Kalium } & \multirow{2}{*}{$\begin{array}{l}\mathrm{Ca} \\
\mathrm{Co}_{3} \\
\%\end{array}$} & \multirow[t]{2}{*}{ Pn } \\
\hline & & & & & $\begin{array}{c}\text { Amazi } \\
\text { ng } \\
\text { acne }\end{array}$ & $\begin{array}{c}\text { Amm } \\
\text { onia } \\
\text { solub } \\
\text { le in } \\
\text { water }\end{array}$ & $\begin{array}{l}\text { Nitra } \\
\text { tes }\end{array}$ & $\begin{array}{c}\text { Perc } \\
\text { ent } \\
\text { of } \%\end{array}$ & $\begin{array}{c}\text { MOBI } \\
\text { LE } \\
\text { mg / } \\
\text { kg }\end{array}$ & $\begin{array}{l}\text { Perce } \\
\text { nt of } \%\end{array}$ & $\begin{array}{l}\text { Purp } \\
\text { ose } \\
\text { mg / } \\
\text { kg }\end{array}$ & & \\
\hline \multicolumn{14}{|c|}{ No erosion } \\
\hline \multirow{4}{*}{1} & A1 & $0-12$ & 5.15 & 0.412 & 123.19 & 20.64 & 7.94 & 0.27 & 27.93 & 3.15 & 399.0 & no & 7.0 \\
\hline & A2 & $\begin{array}{c}12-3 \\
7\end{array}$ & 3.21 & 0.280 & 107.10 & 18.90 & 6.30 & 0.22 & 29.03 & 3.10 & $\begin{array}{c}368.2 \\
0\end{array}$ & by no & 7.0 \\
\hline & B & $\begin{array}{c}37-5 \\
8\end{array}$ & 2.23 & 0.118 & 74.40 & 13.95 & 4.03 & 0.13 & 15.54 & 2.97 & $\begin{array}{c}315.0 \\
0\end{array}$ & 4.54 & 7.2 \\
\hline & C & $\begin{array}{c}58-9 \\
7\end{array}$ & 0.92 & 0.088 & 64.44 & 10.67 & 3.05 & 0.10 & 7.32 & 2.94 & $\begin{array}{c}130.7 \\
5\end{array}$ & 4.85 & 7.3 \\
\hline \multicolumn{14}{|c|}{ Medium degree of erosion } \\
\hline \multirow{3}{*}{2} & A2 & $0-9$ & 3.07 & 0.219 & 70.92 & 11.90 & 4.46 & 0.17 & 15.42 & 2.20 & 281.3 & 5.39 & 7.5 \\
\hline & B & $9-32$ & 2.31 & 0.131 & 61.36 & 10.32 & 3.54 & 0.15 & 13.34 & 2.25 & $\begin{array}{c}208.4 \\
0\end{array}$ & 7.61 & 7.7 \\
\hline & BC & $32-55$ & 0.70 & 0.058 & 52.65 & 8.19 & 2.34 & 0.08 & 5.20 & 2.80 & 93.60 & 6.81 & 7.5 \\
\hline
\end{tabular}

The importance of absorbent and aggregate composition is considerable. Structural and aggregate particles (especially greater than $1 \mathrm{~mm}$ ), which are not eroded in these soils, are quite good. Here, large structural particles of more than $1 \mathrm{~mm}$ are $8.57-94.51 \%$, and aggregate (waterproof) particles are larger than $1 \mathrm{~mm}$ in the medium degree erosion type compared to the brown brown soils 31.95-59 in the upper layer, Varies between $39 \%$. However, in the moderately eroded compared to eroded gray-brown soils, larger than $1 \mathrm{~mm}$ aggregate particles have been reduced by $31,16 \%$ in the upper layer by $20,77-21,88 \%$, smaller than $0,25 \mathrm{~mm}$ in the upper layer $15.31 \%$, and down 12.98 to $17.72 \%$ respectively. It is clear from this that erosion has sharply worsened the structure and aggregate composition of the soil by reducing the adhesive humus content. Soil washing occurs when surface volumes are high, with poor surface dehydration, low porosity. This situation is even more dangerous on the slopes. The large number of studies show that the erosion process has deteriorated the mass and porosity of degraded brown soils. In the upper layer of the medium degree of erosion compared to non- 
erosional lands, the volume mass increased by $0.06 \mathrm{q} / \mathrm{cm} 3$, and the porosity decreased by $2,09 \%$ in the upper layer and 2,04-2,27\% on the lower floors. The results of the study show that natural and anthropogenic factors have affected the erosion process in the degraded brown soils. The erosion process in the Shamakhi region has deteriorated its fertility by destroying these lands the best of these measures is to cultivate leguminous herbs in eroded lands, which are very cheap for farming, and to make the soil more suitable for cultivation. Homogeneous herbs are well developed in eroded soils, enrich the soil with organic residues, thereby reducing erosion process and significantly improves soil fertility. The erosion process in the Shamakhi region, south-east of the Greater Caucasus, encompasses a wide range of areas and has drastically reduced crop yields. As a result of anthropogenic factors in aggressive mountain grasses and agrotechnical measures were not carried out in time, the erosion process was strengthened. Because of the fact that the soil is used for a long period of time, the agrochemical composition and other properties of the soil have deteriorated.4. Prevention of erosion in the region, protecting the soil from scattering, rebuilding fertility, and strengthening the erosion against the erosion should be undertaken to further aggravate the situation of crops, mowers and catches.

\section{Literature}

1. Alekperov KA Azarozy in the Azarbaijan and the mushroom erosion. Sorry. EA nyshriyatat. Baku, 1961, pp.

2. Aliev GA Pavlova Bolshoi Kavkaz (in the limits of Azerb. SSR) Part I.Baku, 1978 p.

3. Aliyev B.H, A.C.Musaev and others. Ways to increase agricultural productivity in erosion-affected and erosive lands in Mountainous Areas of Azerbaijan Republic. "Ziya-Nurlan" publishing house. Baku, 2003, $80 \mathrm{~s}$

4. Aliev ZG Problems with water taps of the mountain slopes of Azerbaijan and the paths ee sheshimi. Searching for Teraggi Baku. 2012. 450s.

5. BAudagov. Geomorphology and novel tectonics of the South-East Caucasus Baku, 1973.6. G.Sh.Mamedov. Atlas of the Azerbaijan Republic.izd vo.Elm.Baku.2007. 123pp

6. Sobolev SS Development of erosion processes in the European part of the USSR and the debt crisis. Search in the USSR, M., 1960, T.2, pp. 80-122.

7. ME Salaev. POPULAR Maloga Caucasus. Searching for Azerb. USSR, Baku, 1966, p. 244-251.

8. Sobolev SS Development of erosion processes in the European part of the USSR and the debt crisis. Search in the USSR, M., 1960, T.2, pp. 80-122. 